\section{Knowledge levels of individuals with type 2 diabetes on foot care}

\section{Tip 2 diyabetli bireylerin ayak bakımı konusunda bilgi düzeyleri}

\author{
Pinar Eroğlu ${ }^{1}$ \\ Birsen Yürügen ${ }^{2}$
}

\begin{abstract}
Purpose: In this study, is a descriptive designed to determine the level of knowledge about foot care of individuals with Type 2 diabetes mellitus.
\end{abstract}

Materials and Method: Research consists 165 diabetic patient, (all of them over 40 years old) which admitted İstanbul University Cerrahpaşa Medical Faculty Endocrinology Metabolism Department. As a data collection tool, a questionnaire consisting of 44 questions which is prepared by the researcher was used.

Results. The majority of the participants in the study are poorly educated, inactive and overweight participants in the 60-69 age group. Diabetic neuropathy was found in $44.8 \%$ and diabetic foot was found in $12.7 \%$ while at least one diabetic complication occurred in $65.5 \%$ of diabetic patients.

$66.7 \%$ of the patient with diabetes had general diabetes education and $21.2 \%$ had diabetic foot training. $54.6 \%$ of this educations was given by the diabetes nurses. The majority of the patient with diabetic chronic complications and foot injuries had received diabetes education. As the duration of diabetes increased, the incidence of complications increased. among these complications, retinopathy and cardiovascular diseases were more common in patients with

\section{Özet}

Amaç: Bu çalışma, tip 2 diyabet tanısı almış bireylerin ayak bakımı konusundaki bilgi düzeylerinin belirlenmesi amaciyla tanımlayıc olarak yapılmıştır.

Materyal ve Metot: Araştırma İstanbul Üniversitesi Cerrahpaşa Tip Fakültesi Endokrinoloji Metabolizma Bilim Dalı Diyabet servisine ve polikliniğine başvuran 40 yaş ve üzeri 165 tip 2 diyabetli hastadan oluşmaktadır. Veri toplama aracı olarak 44 sorudan oluşan ve araştırmacı tarafindan hazırlanan bir anket formu kullanılmıştır.

Bulgular: Çalışmaya katılan bireylerin çoğunluğu 60-69 yaş arası grupta, öğrenim düzeyi düşük, çalışmayan ve kilolu kat1lımcilardır. Diyabetlilerin \%65.5'inde diyabete bağlı en az bir komplikasyon gelişirken $\% 44.8$ 'inde diyabetik nöropati ve \%12.7'sinde diyabetik ayak tespit edilmiştir. Diyabetlilerin \%66.7'si genel diyabet eğitimi, \%21.2'si diyabetik ayak eğitimi almıştır. Bu eğitimlerin \%54.6's1 diyabet hemşiresi tarafindan verilmiştir. Diyabete bağlı kronik komplikasyon ve ayak yarası gelişen diyabetlilerin çoğunluğu diyabet eğitimi almıştı. Diyabet süresi artıkça komplikasyon görülme oranı da artmaktaydı. Bu komplikasyonlardan retinopati ile kardiyovasküler hastalıklar 11 yıl üzeri

\footnotetext{
1 M.Sc., Istanbul University, Cerrahpaşa Medical Faculty, Department of Endocrinology Metabolism and Diabetes, pinareroglu55@hotmail.com

2 Prof. Dr., Okan University, Institute of Health Sciences, Department of Internal Medicine Nursing, birsenyurugen@gmail.com
} 

17(2), 700-709. doi:10.14687/jhs.v17i2.5467

diabetes over the 11 years. The proportion of foot injuries in elderly patients participating in the study is higher than other patients.

Conclusion: As a result of the study, it was determined that the patients did not apply their foot care information, did not have foot care training as they need, they applied to the hospital after the problem developed, and only then they were educated. Diabetic individuals can be recommended for the planned education, adequate time for each subject, observation of the results of the trainings and repeated periodicals to overcome these deficiencies.

Keywords: Type 2 diabetes; diabetic foot; diabetes education nurse; patient education; foot care.

(Extended English summary is at the end of this document) diyabetlilerde daha yüksektir. Çalışmaya katılan yaşı hastalardaki ayak yarası oranı, diğer hastalardan daha fazladir.

Sonuç: Çalışmanın sonucunda hastaların ayak bakım1 konusundaki bilgilerini uygulamaya geçirmedikleri, yeteri kadar ayak bakımı eğitimi almadıkları, sorun geliştikten sonra hastaneye başvurdukları ve ancak o zaman eğitim aldıkları belirlendi. Diyabetli bireylere verilen eğitimlerin planlı olmas1, her konuya yeterli zaman ayrılmas1, eğitimlerin sonuçlarının gözlemlenmesi ve belirli aralıklarla tekrarlanması bu eksikliklerin giderilmesi için önerilebilir.

Anahtar Kelimeler: Tip 2 diyabet; diyabetik ayak; diyabet eğitim hemşiresi; hasta eğitim; ayak bakım1.

\section{GİRİŞ}

Diabetes Mellitus (DM), kısmi insülin eksikliği, insülin direnci ya da her ikisine bağlı olarak gelişen, sistemik ve kronik komplikasyonların eşlik ettiği, sıklığı giderek artan bir metabolizma hastalı̆̆ıdır. Diyabetin kronik komplikasyonlarından biri olan diyabetik ayak, makrovasküler hastalık ve mikrovasküler hasar ile seyreden nöropati ve iskeminin eşlik etmesiyle hızlanan enfeksiyon, ülser ve gangren gelişimini kolaylaştıran ve sonunda morbidite ve mortaliteye sebep olan tedavisi zor, uzun ve maliyeti yüksek bir sağlık problemidir (TEMD 2019). Ayaklar hem diyabetlilerde hemde sağlıklı insanlarda yaralanma, travma ve enfeksiyon oluşumuna en açı olan organımızdır. Diyabetlilerde ayak yarası daha kolay ve hızlı oluşmaktadır. Bunun sebeplerin arasında ayak ve parmaklardaki koruyucu duyunun azalması, kan dolaşımının ayaklarda yavaşlaması, terleme kaybı sonucu kuruluk ve çatlakların oluşması, periferik damar hastalığı ve görme bozuklukları sayılabilir (Koçak\&Olgun, 2009; Kır Biçer \&Çelik, 2016). Diyabetik ayak ülserlerinin yıllık insidans $\% 1$ ile $\% 6,84$ arasındadır ve bir diyabetli bireyde yaşam boyu görülme riski $\% 15$ ile \%25 arasında değişmektedir(Kirsner ve ark. 2010). Diyabetik ayak yaraları, hastaların hastanede uzun süre yatışlarının en önemli nedenlerinden biridir. Yara oluşmadan alınacak önlemler ve oluşmuş olan diyabetik ayak yarasının hızlıca tedavisi, ampütasyonları ve morbiditeyi azaltmakta ve diyabete bağlı yüksek maliyeti düşürmektedir (Kır Biçer, 2017).

Günümüzde hasta eğitimi diyabet tedavisinin en önemli basamaklarından biridir ve diyabetik ayak oluşumunu önlemenin temelini oluşturmaktadır. Diyabetli hastaların eğitimi ile ayak bakımının sağlanması, diyabetik ayak için risk faktörlerinin belirlenerek gerekli tedbirlerin alınması ile ayak ülserlerinin ve ampütasyonlarının önemli ölçüde azalabileceği tahmin edilmektedir(Yücel\&Sunay 2016, Kır Biçer, 2017). Hasta eğitimi diyabetik ayak oluşumunu önlemenin temelini oluşturmaktadır. Yapılan bir çalışmada diyabete ilişkin eğitim alan hastaların çoğunluğunun ayak bakımı ile ilgili bilgi almadığ1 görülmüştür. (Nural\&Hindistan 2015; Yücel\&Sunay 2016). DM hastalarında özel bir önem taşıyan ayak bakımına daha fazla özen gösterilmesi ve hastalığa dair bilgilendirilme esnasında ayak bakımına özellikle değinilmesi gerekmektedir. 
Ülkemizde diyabetli hastaların eğitiminin yeterli olmaması ve hastaların enfeksiyon ilerledikten sonra hastaneye başvurmaları ampütasyon oranını artırmaktadır. Bu nedenle hemşirelerin diyabetik hasta eğitimi içinde, özellikle ayak bakımına daha fazla önem vermesi, zaman ayırması ve hastaları düzenli olarak takip etmesi gerekmektedir (TEMD, 2019; Tuğrul, 2014). Literatür 1şığında diyabetik hastaların tedavi ve ayak bakımı konusundaki bilgi düzeyleri arttıkça komplikasyon gelişme oranlarının azaldığı bilinmektedir (Güner, 2005). Bu bilgiler doğrultusunda çalışmamızın amacı tip 2 diyabetli bireylerin ayak bakımı konusundaki bilgilerini belirlemek ve bireylerin alacakları eğitimlerin biçimlenmesine 1şık tutmaktır.

\section{GEREÇ ve YÖNTEM}

\section{Araştırmanın Tipi ve Örneklemi}

$\mathrm{Bu}$ araştırma tip 2 diyabetli bireylerin ayak bakımı konusundaki bilgi düzeylerinin belirlenmesi amacıyla tanımlayıcı olarak planlanmıştır. Araştırmanın evrenini 2017 Şubat-Mart-Nisan aylarında İstanbul Üniversitesi Cerrahpaşa Tıp Fakültesi Endokrinoloji Metabolizma Bilim Dalı Diyabet servisine yatan ve polikliniğine başvuran 40 yaş ve üzeri tip 2 diyabetli bireyler oluşturmaktadır. Evren sayısını belirlemek için 2016 Ekim-Kasım-Aralık aylarında servise yatan ve polikliniğge başvuran hasta sayıları incelenmiş ve toplam 1240 (1200 polikliniğe başvuran +40 servise yatan) hastadan evreni bilinen örneklem hesaplamasına göre iletişim kurabilen, psikiyatrik tanısı olmayan, 40 yaş ve üzeri tip 2 diyabetli 165 hasta rastgele örnekleme yöntemi ile seçilmiştir.

\section{Verilerin Toplanması ve Değerlendirilmesi}

Araştırma da verilerin toplanması amacıyla 44 sorudan oluşan ve araştırmacı tarafindan hazırlanan bir anket formu kullanılmıştır. Anket formunda diyabetli hastaların sosyo-demografik özellikleri (yaş, cinsiyet, öğrenim düzeyi, meslek vb), diyabet hastalığı ve ayak bakımı ile ilgili bilgilerini içeren sorular bulunmaktadır. Anket uygulanmadan önce diyabetli bireylere araştırma hakkında bilgi verilerek yazılı onayları alınmıştır. Anket formu diyabetli bireylerle yüz yüze görüşme yapılarak uygulanmıştır. Araştırmanın kurum izni İstanbul Üniversitesi Cerrahpaşa Tıp Fakültesi dekanlığından, etik kurul izni Okan Üniversitesi Sağlık Bilimleri Enstitüsü Etik kurulundan (Say1/Yı1:76/06.06.2016) alınmıştır. Çalışmada elde edilen bulguların değerlendirilmesinde, tanımlayıcı istatistik ortalama, standart sapma, medyan, frekans ve oran değerleri kullanıldı. Analizler SPSS 22.0 programı, sonuçlar $\%$ 95'lik güven aralı̆̆1 ve anlamllık $\mathrm{p}<0.05$ düzeyinde değerlendirildi.

\section{BULGULAR}

Araştırma verileri 165 tip 2 diyabetli hastadan toplanmıştır. Hastaların çoğunluğu 60-69 yaş grubunda olup, çalışmaya katılan bireylerin \%52.1'inin kadın, \%47.9'unun erkek, \%58.2'sinin ilköğretim mezunu olduğu saptanmıştır. Hastalıkla ilgili parametreler değerlendirildiğinde hastalık yllları çoğunluğun (\%33.9) $\geq 16$ yll, Beden Kitle İndeksleri (BMI) \%12.7'sinin normal kilolu, büyük

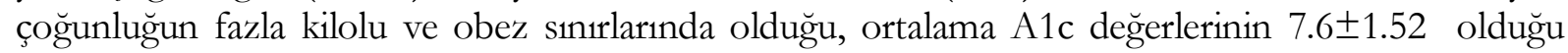
ancak \%37.6'sının A1c değerinin 7'nin altında olduğu ve \%46.7'sinin diyabet tedavisi için kombine tedavi (OAD+insulin) kullandığı saptanmıştır. Diyabetik ayakla ilişkili risk faktörleri değerlendirildiğinde hastaların yarısının (50.9\%) sigara kullanıyor/bırakmış olduğu, \%65.5'inde diyabete bağlı en az bir komplikasyon geliştiği, \%44.8'inde diyabetik nöropati, \%16.4'ünde diyabetik nefropati ve \%12.7'sinde diyabetik ayak yarası oluştuğu saptanmıştır. Diyabetli bireylerin \%66.7'sinin diyabetle ilgili eğitim aldığı, bu eğitimlerin dağılımına bakıldığında çoğunluğunun (62.4\%) insülin kullanımı ve ilaç tedavisi (18.8\%) konusunda olduğu sadece \%21.2'sinin ayak bakımı ile ilgili olduğu belirlenmiștir.

Tip 2 diyabetli bireylerin ayak bakımı ile ilgili bilgilerini belirlemek için sorduğumuz soruların verileri Tablo 1'de yer almaktadır. Diyabetlilerin \% $\%$.4'ü her gün ayağını çatlak, yara, renk değişikliği yönünden kontrol ettiğini, \%20.6's1 kontrol etmediğini, \%36.4'ü ayaklarına krem kullandığını, \%63.6'sı kullanmadığını, \%88.5'i üşüyen ayağını çorap ile 1sıttığını, \%11.5'i diğer yöntemleri (sıcak su 
Eroğlu, P., \& Yürügen, B. (2020). Tip 2 diyabetli bireylerin ayak bakımı konusunda bilgi düzeyleri. Journal of Human Sciences, 17(2), 700-709. doi:10.14687/ihs.v17i2.5467

torbası, soba, ovuşturmak) kullandığını, \%48.5’i ayak tırnaklarına bakım yaptığını, \%51.5’i bakım yapmadığını, \%95.2'si ayak tırnaklarını düz fazla kısa olmayacak şekilde kestiğini, \%84.9’u ayak tırnaklarını keserken kanatmadığını ifade etmiştir (Tablo 1).

Ayak tomaklarm siz mi kesersiniz? sorusuna diyabetlilerin \%86.1'i kendi kestiğini, \%13.9'u kendi kesmediğini belirtmiştir. Tip 2 diyabetli bireylerin \%34.5'i düzenli egzersiz yaptığını, \%41.2'si yalınayak yürüdüğünü, \%18.8’i çorapsız ayakkab1 giydiğini, \%58.2'si ayakkabılarının içini her gün kontrol ettiğini belirtmiştir (Tablo 1). Ayaklarmı̨n tabanlarm nasıl kontrol edersiniz? sorusuna katılımcıların \%70.3'ü kendisinin kontrol ettiğini, \%5.5'i ayna kullandığını, \%13.9'u ailesinden yardım aldığını, \%10.3'ü yalnız doktora gittiğinde bakıldığını ifade etmiştir. Diyabetli bireylerin ayağında çıkan yaralar daha mı zor tedavi edilir? sorusuna ise hastaların \%97.6'sı evet yanıtını vermiştir (Tablo 1).

\begin{tabular}{|c|c|c|c|c|}
\hline \multicolumn{5}{|c|}{$\begin{array}{l}\text { Tablo 1: Tip } 2 \text { diyabetli bireylerin ayak bakımı bilgilerine ilişkin verilerinin } \\
\text { dağılımı (n:165) }\end{array}$} \\
\hline \multirow[b]{2}{*}{ Ayak bakımı ile ilgili bilgi durumu } & \multicolumn{2}{|c|}{ Evet } & \multicolumn{2}{|c|}{ Hayır } \\
\hline & $\mathbf{n}$ & $\%$ & $\mathbf{n}$ & $\%$ \\
\hline $\begin{array}{l}\text { Her gün ayağınızı çatlak, yara, renk } \\
\text { değişikliği yönünden kontrol eder misiniz? }\end{array}$ & 131 & 79.4 & 34 & 20.6 \\
\hline Ayaklarınıza krem kullaniyor musunuz? & 60 & 36.4 & 105 & 63.6 \\
\hline Ayak tırnaklarınıza bakım yapar mısınız? & 80 & 48.5 & 85 & 51.5 \\
\hline $\begin{array}{l}\text { Ayak tırnaklarımı düz fazla kısa } \\
\text { olmayacak şekilde keserim sizce doğru mu? }\end{array}$ & 157 & 95.2 & 8 & 4.8 \\
\hline Ayak tırnaklarını keserken kanatır mısınız? & 25 & 15.1 & 140 & 84.9 \\
\hline Ayak tırnaklarınızı siz mi kesersiniz? & 142 & 86.1 & 23 & 13.9 \\
\hline Düzenli egzersiz yapar mısınız? & 57 & 34.5 & 108 & 65.5 \\
\hline Yalınayak yürür müsünüz? & 68 & 41.2 & 97 & 58.8 \\
\hline Çorapsız ayakkabı giyer misiniz ? & 31 & 18.8 & 134 & 81.2 \\
\hline $\begin{array}{l}\text { Ayakkabınızın içini her gün kontrol } \\
\text { eder misiniz? }\end{array}$ & 96 & 58.2 & 69 & 41.8 \\
\hline $\begin{array}{l}\text { Diyabetli bireylerin ayağında çıkan } \\
\text { yaralar daha mı zor tedavi edilir? }\end{array}$ & 161 & 97.6 & 4 & 2.4 \\
\hline
\end{tabular}

Diyabetlilerin \%75.2'si açı renk pamuklu, \%29.1'i yünlü bilekleri sıkmayan, \%6.1'i naylon rengi önemli değil, \%3’ü sentetik açık renk çorap seçtiğini ifade etmiştir. Tip 2 diyabetli bireylerin \%83’ü ayağına tam uyan yuvarlak burunlu, \%12.1'i ayağından biraz büyük, $\% 2.4$ '̈u sivri burunlu, \%1.2'si yüksek topuklu, \%4.8’i önü açık ayakkab1 seçtiğini belirtmiştir (Tablo 2).

Ayağmı̨da ufak bir yara olsa ne yaparsmı?? sorusuna olguların \%67.9'u doktora giderim, \%23'ü kendim müdahale ederim, \%2.4'ü tanıdıklarıma danışırım, \%3.6's1 kendiliğinden iyileşmesini beklerim, \%3.1'i pansuman yapmaya çalışırım yantını vermiştir. Diyabetli hastalar düzenli ayak bakımı yapmalı diyenlerin oranı $\% 97$, sigara içen diyabetlilerin ayağında içmeyenlere göre daha fazla yara oluşur diyenlerin oranı \%92.1 olarak saptanmıştır. Diyabetli bireylerin ayağznda diğer insanlara oranla daha fąla yara oluşur siz̧ce doğru mu? sorusuna çalısmaya katılanların \%91.5’i evet, \%8.5'i hayır yanıtını vermiştir (Tablo 2). 


\begin{tabular}{|c|c|c|}
\hline & $\mathrm{n}$ & $\%$ \\
\hline \multicolumn{3}{|l|}{ Ayak tabanını kontrol etme yöntemi } \\
\hline Ayna kullanırım & 9 & 5.5 \\
\hline Kendim bakmaya çalışırım & 116 & 70.3 \\
\hline Aileden birinden yardım alırım & 23 & 13.9 \\
\hline Yalnızca doktora gittiğimde bakılır & 17 & 10.3 \\
\hline \multicolumn{3}{|l|}{ Üşüyen ayağını 1sıtma yöntemi } \\
\hline Çorap giymek & 146 & 88.5 \\
\hline Sicak su torbas1 & 13 & 7.9 \\
\hline Soba & 3 & 1.8 \\
\hline Ovuşturma & 3 & 1.8 \\
\hline \multicolumn{3}{|l|}{ Çorap seçimi } \\
\hline Yünlü bilekleri s1kmayan & 48 & 29.1 \\
\hline Açık renk pamuklu & 124 & 75.2 \\
\hline Naylon rengi önemli değil & 10 & 6.1 \\
\hline Sentetik aç1k renk & 5 & 3.0 \\
\hline \multicolumn{3}{|c|}{ Ayakkabı seçiminde dikkat edilen noktalar * } \\
\hline Ayağa biraz büyük & 20 & 12.1 \\
\hline Ayağa tam uyan yuvarlak burunlu & 137 & 83.0 \\
\hline Sivri burunlu & 4 & 2.4 \\
\hline Yüksek topuklu & 2 & 1.2 \\
\hline Önü açık rahat ayakkabı & 8 & 4.8 \\
\hline \multicolumn{3}{|l|}{ Ayağında ufak bir yara açılırsa } \\
\hline Kendim müdahale ederim & 38 & 23.0 \\
\hline Tanıdıklarıma danışırım & 4 & 2.4 \\
\hline Doktora giderim & 112 & 67.9 \\
\hline Kendiliğinden iyileşmesini beklerim & 6 & 3.6 \\
\hline Pansuman yapmaya çalışırım & 5 & 3.1 \\
\hline \multicolumn{3}{|c|}{$\begin{array}{l}\text { Diyabetli bireylerin ayaklarında diğer insanlara } \\
\text { oranla daha fazla yara olabilir sizce doğru mu? }\end{array}$} \\
\hline Evet & 151 & 91.5 \\
\hline Hayır & 14 & 8.5 \\
\hline \multicolumn{3}{|c|}{ Sigara içen diyabetlilerin ayaklarında içmeyenlere } \\
\hline Evet & 152 & 92.1 \\
\hline Hayır & 13 & 7.9 \\
\hline \multicolumn{3}{|c|}{ Diyabetli hastalar düzenli ayak bakımı yapmalı mıdır? } \\
\hline Evet & 160 & 97.0 \\
\hline Hayır & 5 & 3.0 \\
\hline
\end{tabular}

Tip 2 diyabetli bireylerin \%77.6's1 diyabetik ayak konusunda eğitim almak istediğini, \%22.4’ü eğitim almak istemediğini ifade etmiştir. Diyabetlilerin \%25.5’i radyo TV'de eğitici programlar olmas1, \%26.7'si herhangi bir önerisinin olmadı̆̆1, \%28.5’i bireysel eğitim verilmesi konusunda öneri de bulunmuştur (Tablo 3). 
Eroğlu, P., \& Yürügen, B. (2020). Tip 2 diyabetli bireylerin ayak bakımı konusunda bilgi düzeyleri. Journal of Human Sciences, 17(2), 700-709. doi:10.14687/jhs.v17i2.5467

\begin{tabular}{|c|c|c|}
\hline \multicolumn{3}{|c|}{ Tablo 3. Diyabetik ayak eğitimi ile ilgili verilerin dağ1lımı (n:165*) } \\
\hline Diyabetik ayak ile ilgili bilgi alma isteği & $\mathbf{n}$ & $\%$ \\
\hline Var & 128 & 77.6 \\
\hline Yok & 37 & 22.4 \\
\hline \multicolumn{3}{|l|}{ Hastaların eğitim konusundaki önerileri } \\
\hline Kurs açılsin & 15 & 9.1 \\
\hline Broşür dağıtılsın & 36 & 21.8 \\
\hline Radyo TV'de eğitici programlar olsun & 42 & 25.5 \\
\hline Bireysel eğitim verilsin & 47 & 28.5 \\
\hline Herhangi bir önerim yok & 44 & 26.7 \\
\hline
\end{tabular}

* Birden fazla yanıt verilmiştir.

\section{TARTIŞMA}

Diyabetik ayak, eğitim ile önlenebilen diyabetin kronik komplikasyonlarından biridir. Yani diyabetli bireyin tedavisinin başarılı olması için hem hastalık hem de bakım hakkında doğru ve etkin bir biçimde eğitilmesi önemlidir.

Araştırma sonuçları değerlendirildiğinde, hastaların çoğunluğunun ileri yaş ve diyabet yıllarının fazla olması ( $\geq 16$ yıl) diyabetik ayak komplikasyonu gelişmesi açısından önemli bir risk faktörüdür. Literatüre göre ileri yaş ve 10 yllın üzerinde diyabeti olanların ayak komplikasyonu açısından risk taşıdıkları görülmektedir. Aynı zamanda sigara kullanımı, A1c değerinin yüksek olması

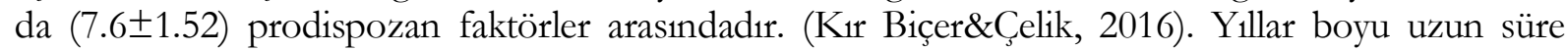
devam eden yüksek kan şekeri diyabetli de birçok kronik komplikasyonun gelişmesine neden olmaktadır. Çalışmaya katılanların \%65.5'inde diyabete bağlı en az bir komplikasyon geliştiği ve gelişen komplikasyonların \%24.9 diyabetik retinopati, \%16.4 diyabetik nefropati, \%9.7 kardiyovasküler hastalık, \%44.8 diyabetik nöropati ve \%12.7 oranında diyabetik ayak olduğu görülmüştür.

Ayaklar hem diyabetlilerde hem de sağllklı insanlarda zedelenme, travma ve enfeksiyon oluşumuna en açı olan organımızdır. Ayak ve parmaklardaki koruyucu duyunun azalması, kan dolaşımının yavaşlaması, terleme kaybı sonucu kuruluk ve çatlakların oluşması, periferik damar hastalı̆̆1 ve görme bozukluğu ile risk artmaktadır (Kır Biçer, 2017). Çalışmadaki nöropati yüzdesinin yüksek ve hastaların ayak bakımı konusunda yeteri kadar eğitim almamış olması diyabetliler de travma ve ayak yarası oluşma riskinin olduğunu göstermektedir.

Araştırmamızda diyabetlilerin 2/3'ünün eğitim aldığı ve bu eğitimlerin \%21.2'sinin diyabetik ayak konusunda olduğu saptanmıştır. Günümüzde yeni diyabet tanısı almış bireylerin hastanede kalış süresinin kısa olması ve hasta yoğunluğundaki artış nedeni ile hemşireler kan şekeri takibi, insülin uygulamaları, diyet ve egzersiz gibi eğitim konularına değinirken ayak bakım eğitimine yeteri kadar zaman ayıramamaktadır. Bununla birlikte hiperglisemi, diyabetik ketoasidoz ve hipoglisemi gibi diyabetin akut komplikasyonları ile uğraşırken eğitimlerini sürdürmeye çalısmaktadırlar (Kır Biçer, 2017; Smeltzer\& Bare, 2004). Tüm bu kompanentlerin arasında ayak bakımına ilişkin öz bakım davranışlarını vurgulamak zor olmaktadır. Ayak yaralarının oluşumunu engellemek ya da erken tespit etmek için diyabetlilerin ayak bakımı ve diyabet konusunda eğitim almaları son derece önemlidir (Kır Biçer, 2017).

Literatürde diyabetik ayak eğitiminin diyabetik ayak hakkındaki bilgi, tutum ve davranışları iyileştirdiğine yönelik çalışmalar bulunmaktadır (Biçer\&Enç, 2016; Aalaa ve ark. 2012; Batkın \&Çetinkaya, 2005). Batkın ve Çetinkaya (2005) ayak bakımı hakkında bilgi alanların davranış puanlarının bilgi almayanlara göre anlamlı ölçüde yüksek olduğunu saptayarak eğitimin önemine değinmiş, Biçer ve Enç'in (2016) çalışmasında diyabetik ayak eğitimi verilen hastaların, standart takip edilen hastalara göre 6 ay sonraki uygulamalarının iyileştiği saptanmıştır (Biçer\&Enç, 2016; Batkın\&Çetinkaya, 2005). Sözen ve Kızılcı'nın (2012) İzmir'de yaptığı çalısmada diyabetik ayağı olan bireylerin ayak bakımı davranışlarını diyabetik ayağı olmayanlara göre anlamlı derecede düşük uygulamakta olduğu saptanmıştır (WUWHS 2016; Sözen\&Kızılc1, 2012; Biçer\&Enç, 2016). 

17(2), 700-709. doi:10.14687/jhs.v17i2.5467

Güner’in (2005) çalışmasında ise eğitim programına katılan diyabetlilerde katılmayanlara göre daha fazla ayak yarası oluştuğu belirlenmiş. Bu çalışmada ise diyabet eğitimi alan hastalarda ayak yarası ve komplikasyon görülme oranı daha yüksek saptanmıştır. Bunun sebebi olarak çalışmayı yaptı̆̆ımız hastanenin hasta potansiyelinin fazla ve çalışan sayısının az olmasına bağlı koruyucu sağlık hizmetlerinin aksaması, hastaların sorun yaşadıktan sonra hastaneye başvuruyor olmaları, eğitimlerde ayak bakımına yeterli zaman ayrilmaması düşünülmüştür. Gerek diyabet eğitimi alan hastalardaki olumlu davranış değişiklikleri gerekse ayak yarası oluşumunun eğitimle ilişkisi diyabetik ayak yarası gelişiminde eğitimin ne kadar önemli olduğunu göstermektedir (Güner, 2005).

Diyabetik ayak yarasının önleminin ilk aşaması erken teşhistir. Bunun içinde hastaların her gün ayağını kontrol etmeleri gerekmektedir. Çalışmamızda da hastaların ayak bakımı konusundaki bilgilerini görmek amacıyla yaptıkları olumlu ve olumsuz davranışlar incelenmiştir. Güner'in (2005) çalışmasında hastaların \%68.9'u, Aypak ve arkadaşlarının (2012) yaptığı çalışmada hastaların \%69.5'i, Göç'ün (2008) çalışmasında hastaların \%56.4'ü her gün ayağını kontrol ettiğini belirtmiştir (Güner, 2005; Göç, 2008; Aypak ve ark., 2012). Araştırmamızda "Her gün ayağımı̨̨ çatlak, yara, renk değğsikliüi yönünden kontrol eder misiniz??" sorusuna diyabetlilerin \%79.4'ü "evet" olarak yanttlamış ve diğer çalısmalara göre daha yüksek oranda uygulama yaptıkları saptanmıştır.

Nöropatinin etkisiyle diyabetik hastalarda ayaklarda üşüme çok sık görülmektedir. Üşüyen ayağını 1sıtmak için sıcak su torbası, soba gibi ayakta yanığa neden olan zarar verici yöntemler yerine

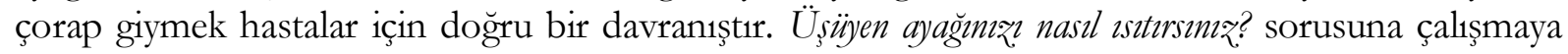
katılan bireylerin \%88.5'i çorap giyerek, \%7.9’u sicak su torbas1, \%1.8'i sobada 1sıtarak, \%1.8'i ovuşturarak yanıtını vermiştir. Güner'in (2005) çalışmasında hastaların \%84.4'ünün üşüyen ayağını çorap ile 1sıttığını, Aypak ve arkadaşlarının (2012) yaptığı çalışmada hastaların \%17'si üşüyen ayaklarını 1sıtmak için ütü, soba, sıcak su torbası veya 1sitıc1 petler gibi yöntemler kullandığını, Göç'ün (2008) çalışmasında hastaların \%71.8’i üşüyen ayağını çorap giyerek ısıttı̆̆ını belirtmiştir (Güner, 2005; Göç, 2008; Aypak ve ark., 2012). Çalışma sonuçlarımız literatürle benzer saptanmıştır.

Diyabetli bireylerde tırnak kesimi ve tırnak bakımı da önem taşır. Diyabet eğitimlerinde bu konuya da değinilmelidir. Ayak tırnaklarına bakım yapanlar katılımcıların \%48.5’ini, ayak tırnaklarını düz fazla kısa olmayacak şekilde doğru kesenler \%95.2'sini, tırnaklarını kendi kesebilenler \%86.1'ini, ayak tırnaklarını keserken kanatmayanlar \%84.9'unu oluşturmuştur. Güner'in (2005) çalışmasında hastaların \%58.9'unun tırnaklarını doğru şekilde kestiği, \%76.7'sinin tırnaklarını keserken kanatmadığı, Aypak ve arkadaşlarının (2012) çalışmasında \%63'ünün tırnaklarını düz sivri olmayacak şekilde kestiği, Nural ve Hintistan'ın (2009) çalışmasında \%73'ünün tırnaklarını doğru şekilde kestiği saptanmıştır (Güner, 2005; Aypak ve ark., 2012; Nural \& Hintistan, 2009). Araştırma sonuçları ile çalışma bulguları benzerlik göstermiş olup diyabetlilerin çoğunluğunun tırnak kesimi konusunda doğru davrandığı görülmüştür.

Bireylerin günlük ayak bakımlarının içinde ayakların her gün yıkanması, kremlenmesi yer almalıdır. Araştırmadaki bireylerin \%36.4’ü ayaklarına krem kullandıklarını belirtmiştir. Güner'in (2005) çalışmasında da hastaların \%27.8'i ayaklarına krem veya talk pudra kullandıklarını ifade etmiştir (Güner, 2005). Corap seçerken nelere dikkeat edersiniz? sorusuna diyabetlilerin \% 75.2'si açık renk pamuklu, \%29.1'i yünlü bilekleri sıkmayan, ayakkabr segerken nelere dikekat edersiniz? sorusuna hastaların \%83'ü ayağıma tam uyan yuvarlak burunlu yanıtını vermiştir. Güner'in (2005) çalışmasında hastaların \%68.9'u uygun ayakkabı seçtiğini, Nural ve Hintistan'ın (2009) çalışmasında \%74.4'ü ayağına tam uyan ayakkabı seçtiğini, \%43.9’u çorap seçerken dikkat ettiğini belirtmiştir (Güner, 2005; Aypak ve ark., 2012; Nural\&Hintistan, 2009).

Araştırmaya katılanların \%41.2'si yalınayak yürüdüğünü, \%18.8'i çorapsız ayakkabı giydiğini, \%58.2'si ayakkabılarının içini her gün kontrol ettiğini ifade etti. Güner'in (2005) çalışmasında hastaların \%65.6'sının yalınayak yürüdüğü, Nural ve Hintistan'ın (2009) çalışmasında \%43.2'sinin yalınayak dolaştı̆̆1, \%16.2'sinin çorapsız terlik giydiği, Göç'ün (2008) çalışmasında \%60.9’unun ayakkabılarını giymeden önce kontrol ettiği belirlenmiş (Güner, 2005; Göç, 2008; Nural \& Hintistan, 2009). Araştırma sonuçlarımız değerlendirildiğinde hastaların çoğunluğunun ayağı nemlendirmek için 
krem kullandıkları, çorap ve ayakkabı seçimi konusunda doğru bilgi ve uygulamaya sahip oldukları görülmüştür.

Diyabetli bireyler ayaklarını her gün kontrol etmeli, ufak bir yara olduğunda ilk olarak doktora başvurmalıdır. Çünkü diyabetik ayak yarası çabuk ve sinsi ilerleyen aynı zamanda geç iyileşen bir problemdir (Arıcan \& Şaşmaz, 2004). Bu doğrultu da bireylere sorduğumuz ayağında ufak biryara olsa ne yaparsinı?? sorusuna hastaların \%67.9'u doktora giderim, \%23’ü kendim müdahale ederim, \%3.1’i pansuman yaparım, \%3.6'sı kendiliğinden iyileşmesini beklerim diyerek bilgilerini bizimle paylaşmıştır. Diyabetlilerin çoğunluğunun ilk doktora başvurmak istemeleri doğru bir seçenek olarak değerlendirilirken bir kısmının kendim müdahale ederim veya pansuman yaparım düşüncesinde olmaları diyabetik ayak açısından risk altında olduklarını göstermektedir.

Ayağınızın tabanını nasıl kontrol edersiniz? sorusuna \%5.5’i ayna kullanırım, \%70.3'ü kendim bakmaya çalışıım, \%13.9'u ailemden yardım alıım, \%10.3'ü yalnız doktora gittiğimde bakılır yanıtını vermiştir. Nural ve Hintistan'ın (2009) çalışmasında hastaların \%40.5'i ayaklarına kendisi baktığını, \%33.6's1 aileden birisinden destek aldığını, \%6.7'si yalnız doktora gittiğinde kontrol edildiğini, \%5.4'ü ayna kullandığını ifade etmiştir (Nural \& Hintistan, 2009). Çalışmamıza katılan diyabetlilerin çoğunluğunun kilolu, komplikasyonları olan bireylerden oluşması aile desteğine ihtiyaçları olduklarını göstermekte lakin sadece \%13.9'unun ailesinden yardım istemesi gerekli desteği görmediklerini düşündürmektedir.

Tip 2 diyabetli bireylerin \%77.6's1 diyabetik ayak konusunda bilgi almak istediklerini belirtmiştir. Ayak bakımı konusunda diyabetli bireylerin \%28.5'i bireysel eğitim, \%25.5'i radyo TV'de eğitici programlar olsun isterken \%26.7'si hiçbir önerisi olmadığını belirtmiştir. Eğitim almak istemeyen bireylerin olması ayak bakımının önemini yeteri kadar kavramadıklarını, hastaların iyi bir öğrenme yöntemi olan bireysel eğitim yerine diğer seçeneklere de eşit oranda yanıt vermeleri eğitime zaman ayırmak istemediklerini ya da hastane dışı bir ortamda eğitim almak istediklerini düşündürmektedir. Bireylerin eğitim almak istememe nedeni psikolojik desteğe ihtiyaç duyduklarının bir göstergesi de olabilir. Sağlık çalısanlarının, aile ve arkadaşlarının desteğini alan diyabetlilerde uyumun daha iyi olabileceği literatürde yer almaktadır (Akın, 2013).

\section{SONUÇ ve ÖNERİLER}

Araştırma verilerinden elde edilen bulgular doğrultusunda tip 2 diyabetli bireylerin ayak bakımı eğitimlerinin yetersiz olduğu, ayak bakımı konusunda diyabetlilerin çoğunluğunun bilgili oldukları fakat ayak bakımı ile ilgili uygulama da yetersiz kaldıkları belirlenmiştir. Bu sonuçlar doğrultusunda;

- Diyabetli hastalara uygulanan eğitimlerde bütüncül davranılması,

- Eğitim sonrası bireylere görsel materyaller (broşür, kitapçı vb) verilerek evde de eğitimin devaminın sağlanması,

- Radyo, TV, gazete, bilgisayar ve benzeri medya araçları kullanılarak toplum eğitimine önem verilmesi,

- Diyabetik ayak bakımı konusunda bireyin uyumunun sağlanması ve verilecek eğitimin başarılı olabilmesi için aile ve arkadaş desteği sağlanması,

- Çalışma sonuçlarının tüm diyabetli bireylere genellenebilmesi ve diğer çalışmalara örnek teşkil etmesi için daha fazla hastanede, daha fazla hasta ile ayak yarası olan ve olmayan grupların karşılaştırılması ve eğitim öncesi-sonrası izlem yapılarak eğitimlerin etkinliğini ölçen çalışmaların arttırılması önerilmektedir.

\section{KAYNAKLAR}

Aalaa M, Malazy OT, Sanjari M, Peimani M\&Mohajeri-Tehrani M. Nurses' Role in diabetic foot prevention and care; a review", J Diabetes Metab Disord. 2012;Nov 21;11(1):24.

Arıcan Ö\&Şaşmaz S. "Diyabetik hastalarda ayak bakımı” .Türkiye Klinikleri J Med, 2004(24); 541-546. 
Eroğlu, P., \& Yürügen, B. (2020). Tip 2 diyabetli bireylerin ayak bakımı konusunda bilgi düzeyleri. Journal of Human Sciences, 17(2), 700-709. doi:10.14687/jhs.v17i2.5467

Akın Aİ. Tip 2 diyabet hastalarında yaşam kalitesi, hastalıkla ilgili bilgi düzeyi, hastalık algısı, stresle başa çıkma ve depresyon, Okan Üniversitesi Sosyal Bilimler Enstitüsü, Psikoloji Anabilim Dalı Yayınlanmamış Yüksek Lisans Tezi. İstanbul. 2013.

Aypak C, Koç A, Yıkılkan H\&Görpelioğlu S. ”Diyabetik ayak bakımı: aile hekimliği polikliniğine başvuran hastalar tarafindan bildirilen uygulama durumu", Cumhuriyet Tip Dergisi, 2012; 423-428.

Batkın D\&Çetinkaya F. "Diabetes mellitus hastalarının ayak bakımı ve diyabetik ayak hakkındaki bilgi, tutum ve davranışları”, Sağlık Bilimleri Dergisi, 2005,14(1); 6-12.

Biçer, E.K. \& Enç, N. Evaluation of foot care and self-efficacy in patients with diabetes in Turkey: an interventional study, Int J Diabetes Dev Ctries, 2016. 36(3):334-44

Çelik S\&Öztürk G. Diabetic foot; risk factors and care, Diyabet, Obezite ve Hipertansiyonda Hemşirelik Dergisi, 2009;1(1): 22-27.

Güner A. Diyabetik hastaların diyabetik ayak ile ilgili bilgi ve tutumlarının irdelenmesi ve Hba1 c'nin diyabetik ayak ile ilişkisi. In: Sağlık Bakanlı̆̆, TC Taksim Eğitim ve Araştırma Hastanesi Aile Hekimliği (Eds.), Uzmanllk Tezi, İstanbul. 2005.

Göç M. Diyabetes Mellitus'lu hastalarda, hastalığın süresi, hastalarnn öğrenim düzeyi, diyabetik ayakla ilgili eğitim alma durumu, metabolik değerlerin, diyabetik ayak gelişim riski ve diyabetik ayakta koruyucu davranış modelleri geliştirmeye etkileri, Sağlık Bakanlığı Haydarpaşa Numune Eğitim ve Araştırma Hastanesi, Aile Hekimliği Yayınlanmamış Uzmanlık Tezi, İstanbul. 2008.

Kır Biçer E. Patient education for the prevention of diabetic foot wounds. Curre Res Diabetes \& Obes J. 2017; 1(4): 555569.

Kır Biçer E \& Çelik S, Diyabetli hastalar için kapsamlı ayak muayenesi ve risk değerlendirmesi, Turkiye Klinikleri J Nurs Sci 2016;8(1):62-70

Kirsner, R. S., Warriner 3rd, R. A., Lavery, L. A., Hanft, J. R., \& Sheehan, P. Consensus recommendations on advancing the standard of care for treating neuropathic foot ulcers in patients with diabetes Ostomy Wound Manage. 2010 Apr;56(4 Suppl):S1-24.

Koçak KD\&Olgun NTip 2 Diyabetli Hastalarda Ayak Bakım Becerisinin Kazandırılması, Diyabet, Obezite ve Hipertansiyonda Hemşirelik Dergisi, 2009;1(1):2-37.

Nural N \& Hintistan S. Diyabetik hastaların ayak bakımıla ilgili bilgi ve tutumlarının incelenmesi, Anadolu Hemssirelik ve Sağhk Bilimleri Dergisi, 2015,18(2); 116-124.

Smeltzer SC \& Bare BG Medical Surgical Nursing. (8th edn), Lippincott-Raven Publishers Philadelphia, USA. 1996:p. 122.

Sözen E\&Kızılc1 S. Examination and comparison of foot care behaviors of individuals who have type 2 diabetes. Ege Üniversitesi Hemşirelik Fakültesi Dergisi, 2012;28(2): 41-53.

Tuğrul A. Diyabetes mellitus: kontrol ve komplikasyonları" Stoller J.K, Michota F.A, Mandell B.F. Clevenard Klinik İç Hastalıklanı, 5. Baskı, İstanbul Tip Kitapevi, İstanbul.2014:28-44.

Türkiye Endokrinoloji ve Metabolizma Derneği (TEMD). Diabetes mellitus ve komplikasyonlarının tanı, tedavi ve izlem k1lavuzu, Bayt Bilimsel Araşturmalar, 12. Bask1, Ankara, 2019;161-169.

World Union of Wound Healing Societies (WUWHS), Florence Congress, Position Document. Local Management of Diabetic Foot Ulcers. Wounds International, 2016.

Yücel F \& Sunay D. Assessment of Knowledge, Attitudes and Behaviours of Diabetic Patients About Diabetic Foot and Foot Care. Ankara Med J, 2016;16(3): 270-84.

\section{Extended English Summary}

Introduction: Diabetic foot injury, is a problem that requires long-term treatment among chronic complications of diabetes. In diabetes, foot injuries may occur more easily and quickly. Among these reasons, loss of sensation caused by peripheral neuropathy, impaired blood circulation due to peripheral arterial disease, visual impairment, dryness and cracking resulting from loss of sweat. Foot care education is very important in preventing foot problems. It is extremely important for patients with diabetes to be trained in foot care and diabetes to prevent or early detection of foot wounds. In the literature, it is known that as the level of knowledge about treatment and foot care of diabetic patients increases, complication rates decrease. Increasing the knowledge, awareness and self care of the foot among diabetic patients have found to be cost effective ways of preventing DM foot 
Eroğlu, P., \& Yürügen, B. (2020). Tip 2 diyabetli bireylerin ayak bakımı konusunda bilgi düzeyleri. Journal of Human Sciences, 17(2), 700-709. doi:10.14687/jhs.v17i2.5467

ulceration especially in low income economy characterized by inadequate healthcare facilities and lack of skilled healthcare personnel.

Objective: In this study, is a descriptive study designed to determine the level of knowledge about foot care of individuals with Type 2 diabetes mellitus.

Method: This study was planned as descriptive research. Research consists 165 patients with type 2 diabetes, (all of them over 40 years old) which admitted in a major University Hospital, Department of Endocrinology Metabolism and Diabetes. As a data collection tool, a questionnaire consisting of 44 questions which is prepared by the researcher was used.

The questionnaire contains questions about the socio-demographic characteristics (age, gender, education level, occupation etc.), diabetes mellitus and foot care of diabetic patients. Okan University Health Science Institute approved this study (76/06.06.2016). Before the questionnaire was applied, subjects with diabetes were informed about the research and written approval was obtained. The work was conducted in accordance with the principles of the Declaration of Helsinki. The questionnaire was administered face to face with diabetic individuals. Descriptive statistical methods (mean, standard deviation, median, frequency and ratio) were used in the evaluation of findings in the study. Analyzes were evaluated using the SPSS 22.0 program, with a 95\% confidence interval and a significance level of $\mathrm{p}<0.05$.

Results. We enrolled a total of 165 diabetic patients to the study, $47.9 \%$ were males and $52.1 \%$ were females. The majority of the participants in the study are poorly educated, inactive and overweight participants in the 60-69 age group. Diabetic neuropathy was found in $44.8 \%$ and diabetic foot was found in $12.7 \%$ while at least one diabetic complication occurred in $65.5 \%$ of diabetic patients. $\quad 66.7 \%$ of the patient with diabetes had general diabetes education and $21.2 \%$ had diabetic foot training. $54.6 \%$ of these educations was given by the diabetes nurses. The majority of the patient with diabetic chronic complications and foot injuries had received diabetes education. As the duration of diabetes increased, the incidence of complications increased. Among these complications, retinopathy and cardiovascular diseases were more common in patients with diabetes over the 11 years. The proportion of foot injuries in elderly patients participating in the study is higher than other patients.

It was found that $79.4 \%$ of the patient checked their feet daily for wounds, color and cracks, $36.4 \%$ had used foot cream, $88.5 \%$ of them heated their cold feet with socks, $86.1 \%$ had their toenails cut themselves, $41.2 \%$ walked barefoot at home, $18.8 \%$ of them wear shoes without socks, $58.2 \%$ checked the inside of their shoes every day. $67.9 \%$ of the cases will be examined by a doctor when the foot was injured, and $23 \%$ said that he would intervene. $77.6 \%$ of individuals with type 2 diabetes reported that they wanted to be informed about diabetic foot. The patients' education preferences were found $28.5 \%$ for individual education, $25.5 \%$ for educational programme on TV and radio. $26.7 \%$ of the patients stated that there was no proposal.

Conclusions: In conclusion, patients with type 2 diabetes were found to be inadequate in their foot care training, knowledge of the majority of diabetic patients on foot care, but had poor foot care practices. As a result of these studies is suggested;

- Holistic approach in diabetes education

- After the training, providing visual materials (brochures, booklets, etc.) for diabetic foot care to patients, thus ensuring the continuing education at home,

- Emphasis on community education by using radio, TV, newspaper, computer and other media tools in foot care

- Increasing individual compliance with diabetic foot care via support from family and friends.

- To achieve the large population for the results of the study to be generalized to all patients with diabetes,

- To comparison of different groups with/without foot wound

- To carry in pre and post-training follow-up studies on foot care 